\title{
Sistem Pendukung Keputusan Pemilihan Jurusan di SMA dengan Analytic Hierarchy Process (AHP)
}

\author{
Desita Aulia Anju, Fajar Agustian, Khalid Ibnu Walid \\ Program Studi Teknik Informatika \\ Jurusan Teknik Informatika dan Komputer \\ Politeknik Negeri Jakarta \\ anjuaulia9@gmail.com,fajaragustianth@gmail.com,khalidblacklist@gmail.com
}

Diterima: 5 April 2018. Disetujui: 25 April 2018. Dipublikasikan: Mei 2018

\begin{abstract}
Abstrak - Sistem Pendukung Keputusan (SPK) adalah sistem yang dapat membantu seseorang dalam mengambil keputusan yang akurat dan tepat sasaran. Banyak permasalahan yang dapat diselesaikan dengan menggunakan SPK, salah satunya adalah pemilihan jurusan di SMA. Ada beberapa metode yang dapat digunakan dalam membangun suatu SPK, diantaranya Analytical Hierarchy Process (AHP). AHP merupakan metode yang paling banyak digunakan dalam memecahkan permasalahan yang bersifat multi kriteria. Penelitian ini menggunakan metode AHP dalam menentukan pemilihan jurusan di SMA. Sistem dirancang dengan menggunakan bahasa pemograman $\mathrm{C} \#$ dan aplikasi SQL Server yang digunakan untuk mengolah data. Data yang diolah berupa empat kriteria (Nilai Akademik, Nilai Psikotest, Minat Siswa, dan dari Orang Tua) untuk tiga alternatif (IPA, IPS, dan Bahasa). Hasil penelitian akan menunjukan sistem pendukung keputusan yang telah dirancang dapat menghasilkan informasi prioritas jurusan yang sesuai dengan kemampuan siswa sehingga dapat digunakan sebagai dasar pengambilan keputusan dalam pemilihan jurusan.
\end{abstract}

Kata Kunci: sistem pendukung keputusan (SPK), analytical hierarchy process (AHP), pemilihan jurusan di SMA; waterfall.

\section{PENDAHULUAN}

Dalam segala pilihan selalu ada pengambilan keputusan yang sangat berpengaruh pada kehidupan. Permasalahan pengambilan keputusan juga dialami oleh siswa yang baru memasuki jenjang Sekolah Menengah Atas (SMA) untuk mengambil jurusan. Banyak hal yang perlu dipertimbangkan dalam pemilihan jurusan yang sesuai. Banyak yang berpandangan dalam pemilihan jurusan yang mudah dan mudah dijalani agar dapat perguruan tinggi, tanpa memperdulikan apakah sesuai pada minat serta bakat. Sebenarnya dalam pandangan seperti ini perlu ditinjau ulang karena pemilihan suatu jurusan bukanlah persoalan yang mudah. Contoh dampak yang dapat ditimbulkan ketika salah memilih jurusan yaitu dalam menjalani suatu aktivitas seperti belajar secara terpaksa, atau gagal dalam pembelajaran. Hal ini dapat dicegah dengan harapan siswa harus lebih dahulu mengetahui kemampuannya. Sistem ini dirancang agar dapat membantu siswa dalam pembelajaran, sehingga membantu dalam mengambil keputusan. Maka dari itu sistem pada penelitian ini dirancang dengan tujuan :

1. Merancang suatu sistem pendukung keputusan untuk membantu siswa dalam memilih jurusan yang sesuai kemampuannya berdasarkan kriteria-kriteria.

2. Pemilihan jurusan berdasarkan kemampuannya dengan menggunakan metode AHP (Analytical Hierarchy Process).

\section{TINJAUAN PUSTAKA}

\section{A. Sistem Pendukung Keputusan}

Sistem Pendukung Keputusan (SPK) atau Decision Support System (DSS) adalah sebuah sistem yang mampu memberikan kemampuan pemecahan masalah maupun kemampuan pengkomunikasian untuk masalah dengan kondisi semi terstruktur dan tak terstruktur. Sistem ini digunakan untuk membantu pengambilan keputusan dalam situasi semi terstruktur dan situasi yang tidak terstruktur, dimana tak seorangpun tahu secara pasti bagaimana keputusan seharusnya dibuat. [1]

Bonczek mendefinisikan SPK sebagai sistem berbasis komputer yang terdiri dari tiga komponen yang saling berinteraksi: sistem Bahasa (mekanisme untuk memberikan komunikasi antara pengguna dan komponen SPK lain), sistem pengetahuan (repository pengetahuan dominan masalah yang ada pada SPK entah sebagai data atau prosedur), dan 
sistem pemrosesan masalah (hubungan antara dua komponen lainnya, terdiri satu atau lebih kapabilitas manipulasi masalah umum yang diperlukan untuk pengambilan keputusan).[1]

Sprague dan Watson mendefinisikan Sistem Pendukung Keputusan (SPK) sebagai sistem yang memiliki lima karakteristik utama yaitu [2] :

1. Sistem yang berbasis komputer.

2. Dipergunakan untuk membantu para pengambil keputusan.

3. Untuk memecahkan masalah-masalah rumit yang mustahil dilakukan dengan kalkulasi manual.

4. Melalui cara simulasi yang interaktif.

5. Data dan model analisis sebagai komponen utama.

\section{B. Model Waterfall}

Jogiyanto menyatakan bahwa model Waterfall ini mengambil kegiatan dasar seperti spesifikasi, pengembangan, validasi, dan evolusi dan merepresentasikannya sebagai fase-fase proses yang berbeda seperti spesifikasi persyaratan, perancangan perangkat lunak, implementasi, pengujian dan seterusnya [3]. Model Waterfall digambarkan pada Gambar 1.

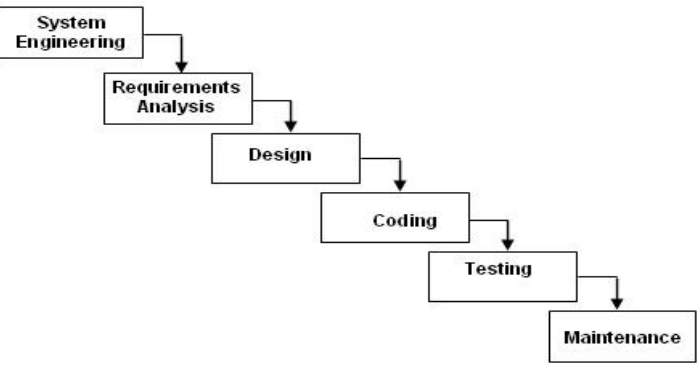

Gambar 1. Model Waterfall

\section{Analytical Hierarchy Process (AHP)}

AHP adalah suatu teori umum tentang pengukuran. AHP digunakan untuk menemukan skala rasio baik dari perbandingan pasangan yang diskrit maupun kontinyu. Perbandinganperbandingan ini dapat diambil dari ukuran aktual atau dari suatu skala dasar yang mencerminkan kekuatan perasaan dan prefensi relatif. [4]

AHP diperkenalkan oleh DR. Thomas L. Saaty di awal tahun 1970. Pada saat itu, AHP dipergunakan untuk mendukung pengambilan keputusan pada beberapa perusahaan dan pemerintahan. Pengambilan keputusan dilakukan secara bertahap dari tingkat terendah hingga puncak. Pada proses pengambilan keputusan dengan AHP, ada permasalahan/goal dengan beberapa level kriteria dan alternatif. Masingmasing alternatif dalam satu kriteria memiliki skor. Skor diperoleh dari eigen vektor matriks yang diperoleh dari perbandingan berpasangan dengan alternatif yang lain. Skor yang dimaksud ini adalah bobot masing-masing alternatif terhadap satu kriteria. Masing-masing kriteria pun memiliki bobot tertentu (didapat dengancara yang sama). Selanjutnya perkalian matriks alternatif dan kriteria dilakukan di tiap level hingga naik ke puncak level. Perbedaan mencolok antara model AHP dengan model pengambilan keputusan lainnya terletak pada jenis inputnya. Model-model yang sudah ada umumnya memakai input yang kuantitatif atau berasal dari data sekunder.

Peralatan utama AHP adalah sebuah hirarki fungsional dengan input utamanya persepsi manusi. Dengan hirarki, suatu masalah kompleks dan tidak terstruktur dipecahkan ke dalam kelompokkelompoknya. Kemudian kelompok-kelompok tersebut diatur menjadi suatu bentuk hirarki. [5]

Kriteria di sini bukan berarti bahwa orang tersebut haruslah genius, pintar, bergelar doktor dan sebagainya tetapi lebih mengacu pada orang yang mengerti benar permasalahan yang diajukan, merasakan akibat suatu masalah atau punya kepentingan terhadap masalah tersebut. Karena merupakan input yang kualitatif atau persepsi manusia maka model ini dapat mengolah juga halhal kualitatif di samping hal-hal kuantitatif.

Analytical Hierarchy Process (AHP) mempunyai landasan aksiomatik yang terdiri dari: [6]

a. Resiprocal Comparison, yang mengandung arti bahwa matriks perbandingan berpasangan yang terbentuk harus bersifat berkebalikan. Misalnya, jika A adalah k kali lebih penting dari pada B maka B adalah 1/k kali lebih penting dari A.

b. Homogenity, yaitu mengandung arti kesamaan dalam melakukan perbandingan. Misalnya, tidak mungkin membandingkan jeruk dengan bola tenis dalam hal rasa, akan tetapi lebih relevan jika membandingkan dalam hal berat.

c. Dependence, yang berarti setiap level mempunyai kaitan (complete hierarchy) walaupun mungkin saja terjadi hubungan yang tidak sempurna (incomplete hierarchy).

d. Expectation, yang berarti menonjolkon penilaian yang bersifat ekspektasi dan preferensi dari pengambilan keputusan. Penilaian dapat merupakan data kuantitatif maupun data kualitatif.

\section{ANALISA DAN PERANCANGAN}

Bab ini membahas analisis kebutuhan dan perancangan sistem pendukung keputusan penjurusan SMA menggunakan metode AHP untuk membantu pihak sekolah memperoleh hasil yang lebih akurat. Perancangan ini meliputi dua tahap yaitu proses analisis kebutuhan perangkat lunak dan 
perancangan sistem pendukung keputusan menggunakan metode AHP (Analytical Hierarchy Process) [7]. Tahap analisis kebutuhan perangkat lunak terdiri dari identifikasi aktor, daftar kebutuhan sistem, dan use case diagram. Tahap perancangan sistem pendukung keputusan terdiri dari langkah metode AHP, hasil keputusan metode AHP dan user interface.

\section{A. Analisis Kebutuhan Perangkat Lunak}

Beberapa fungsi perangkat lunak yang dibutuhkan oleh perangkat lunak terdiri dari identifikasi aktor, daftar kebutuhan sistem dan use case diagram sistem.

\section{B. Identifikasi Aktor}

Di dalam sistem ini terdapat satu aktor yang berperan dalam sistem, yaitu User yaitu aktor/pengguna yang meng-input-kan data dan dapat mengakses fitur, menambah matrik perbandingan kriteria, melihat hasil keputusan dan melakukan tambah matrik perbandingan alternatif.

\section{Daftar Kebutuhan Sistem}

Daftar kebutuhan ini menjelaskan tentang kebutuhan user yang harus disediakan oleh sistem. Dari setiap kolom yang terdapat pada Tabel 1 menampilkan nama masing-masing use case dan menunjukan masing-masing kebutuhan yang diperlukan.

\section{TABEL 1. DAFTAR KEBUTUHAN SISTEM}

\begin{tabular}{|l|l|l|}
\hline \multicolumn{1}{|c|}{ Kebutuhan } & Aktor & \multicolumn{1}{c|}{$\begin{array}{c}\text { Nama Use } \\
\text { Case }\end{array}$} \\
\hline $\begin{array}{l}\text { Sistem harus menyediakan } \\
\text { antar muka untuk } \\
\text { memasukkan inputan } \text { user } \\
\text { berupa matrik perbandingan } \\
\text { kriteria sehingga sistem bisa } \\
\text { memproses dan } \\
\text { menampilkan hasil keputusan }\end{array}$ & User & $\begin{array}{l}\text { Mambah } \\
\text { perbandingan } \\
\text { kriteria }\end{array}$ \\
\hline $\begin{array}{l}\text { Sistem harus menyediakan } \\
\text { antar muka untuk } \\
\text { menampilkan hasil keputusan } \\
\text { untuk dilihat oleh } \text { user }\end{array}$ & User & $\begin{array}{l}\text { Melihat Hasil } \\
\text { Keputusan }\end{array}$ \\
\hline $\begin{array}{l}\text { Sistem harus menyediakan } \\
\text { antar muka untuk } \\
\text { memasukkan inputan user } \\
\text { berupa matrik perbandingan } \\
\text { alternative sehingga sistem } \\
\text { bisa memproses dan } \\
\text { menampilkan hasil keputusan }\end{array}$ & User & $\begin{array}{l}\text { Tambah } \\
\text { perbandingan } \\
\text { kriteria }\end{array}$ \\
\hline
\end{tabular}

\section{Kebutuhan Fungsional}

Dalam sistem ini terdapat beberapa kebutuhan fungsional yang melengkapi fitur-fitur dalam sistem. Berikut adalah kebutuhan fungsional dalam sistem :
Akses sistem untuk tambah matrik perbandingan kriteria menyediakan fasilitas:

- Memasukkan data Nama siswa

- Memasukkan data Nomer induk

- Memasukkan data tempat lahir

- Memasukkan data Tanggal lahir

- Memasukkan data Alamat

- Memilih salah satu (bakat, minat, nilai akademik, nilai psikotest)

Akses sistem untuk penyelesaian masalah menggunakan AHP terdapat empat prinsip dasar yang menyediakan fasilitas:

- Dekomposisi

- Penilaian Komparasi (Comparative Judgement)

- Penentuan Prioritas (Synthesis of Priority)

- Konsistensi Logis (Logical Consistency)

\section{E. Kebutuhan Non-Fungsional}

Sistem dapat menyimpan data siswa dan hasil yang diperoleh siswa secara aman tanpa perlu takut data tersebut dapat diketahui oleh orang lain. Orang yang memiliki hak akses terhadap sistem hanya petugas sekolah (admin), sistem ini dilengkapi dengan tampilan yang menarik dan mudah diakses sehingga siswa tidak perlu bingung saat menggunakan.

\section{F. Use Case Diagram}

Diagram use case merupakan salah satu model UML yang digunakan untuk mendeskripsikan kebutuhan-kebutuhan dan fungsionalitas dari sebuah sistem dari prespektif end user dan menunjukkan aktifitas-aktifitas yang dilakukan oleh user. Gambar 2 menjelaskan user case diagram admin dan user.
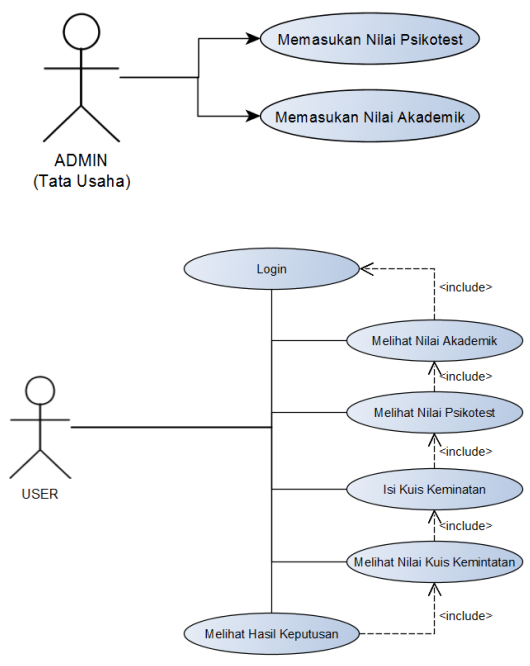

Gambar 2. Use Case Diagram 


\section{G. Skenario Use Case}

Dalam use case di atas diketahui bahwa user dapat mengisi kuis keminatan. Setelah itu sistem menerima data masukan user kemudian mengolahnya dengan metode AHP (Analytical Hierarchy Process), setelah itu user dapat melihat hasil keputusan yang ditampilkan.

User dapat melakukan proses meng-inputkan data yang berupa mengisi kuis keminatan. User juga dapat melihat nilai akademik, melihat nilai psikotest, melihat nilai kuis keminatan, dan melihat hasil keputusan.

Admin atau petugas tata usaha melakukan proses peng-input-an data yang dimasukkan yaitu berupa memasukkan nilai akademik dan memasukkan nilai psikotes. Tabel 2 dan 3 menjelaskan skenario untuk case diagram user.

a. Skenario User

\begin{tabular}{|c|c|}
\hline Usecase & Input data \\
\hline \multicolumn{2}{|r|}{ User } \\
\hline Tujuan & $\begin{array}{l}\text { Inputan data yang dimasukkan } \\
\text { user ini akan digunakan untuk } \\
\text { mendapatkan nilai dari } \\
\text { perhitungan yang dilakukan }\end{array}$ \\
\hline Deskripsi & $\begin{array}{l}\text { Usecase ini menjelaskan } \\
\text { bagaimana proses } u s e r \\
\text { memasukan inputan data }\end{array}$ \\
\hline Kondisi awal & $\begin{array}{c}\text { Akan ditampilkan beberapa soal } \\
\text { pilihan ganda yang digunakan } \\
\text { user untuk menginputkan } \\
\text { jawaban }\end{array}$ \\
\hline Kondisi Akhir & $\begin{array}{c}\text { Input dari } \text { user akan digunakan } \\
\text { untuk menentukan hasil }\end{array}$ \\
\hline \multicolumn{2}{|c|}{ Scenario : mengisi kuis keminatan } \\
\hline Aksi dari $u s e r$ & Tanggapan dari sistem \\
\hline $\begin{array}{ll}\text { 1. } & \text { User } \\
\text { mengisikan } \\
\text { jawaban kuis } \\
\text { kemintan. }\end{array}$ & $\begin{array}{l}\text { Sistem menghitung hasil dari } \\
\text { kuis keminatan user. }\end{array}$ \\
\hline
\end{tabular}

b. Skenario Admin

TABEL 3. SKENARIO ADMIN

\begin{tabular}{|c|c|}
\hline Usecase & Input data \\
\hline Tujuan & $\begin{array}{c}\text { Inputan data yang dimasukan } \\
\text { admin ini akan digunakan untuk } \\
\text { menampilkan nilai akademik } \\
\text { dan nilai psikotes yang dilihat } \\
\text { oleh user. }\end{array}$ \\
\hline Deskripsi & $\begin{array}{c}\text { Usecase ini menjelaskan } \\
\text { bagaimana proses admin } \\
\text { memasukan data kedalam } \\
\text { database. }\end{array}$ \\
\hline Kondisi awal & $\begin{array}{c}\text { Database dalam keadaan } \\
\text { kosong. }\end{array}$ \\
\hline Kondisi Akhir & Database akan terisi dengan \\
& data siswa yang telah \\
\hline
\end{tabular}

\begin{tabular}{|c|c|}
\hline & diinputkan oleh admin. \\
\hline \multicolumn{2}{|c|}{ Scenario : memasukan nilai akademik } \\
\hline Aksi dari admin & Tanggapan dari sistem \\
\hline $\begin{array}{ll}\text { 1. } & \text { Admin } \\
\text { memasukan } \\
\text { inputan data } \\
\text { berupa nilai } \\
\text { akademik. }\end{array}$ & $\begin{array}{c}\text { Sistem menyimpan ke dalam } \\
\text { database. }\end{array}$ \\
\hline \multicolumn{2}{|l|}{$\begin{array}{c}\text { Scenario : memasukan } \\
\text { nilai psikotest }\end{array}$} \\
\hline Aksi dari admin & Tanggapan dari sistem \\
\hline $\begin{array}{ll}\text { 1. } & \text { Admin } \\
\text { memasukan } \\
\text { inputan data } \\
\text { berupa nilai } \\
\text { psikotest. }\end{array}$ & $\begin{array}{c}\text { Sistem menyimpan ke dalam } \\
\text { database. }\end{array}$ \\
\hline
\end{tabular}

H. Perancangan Sistem Pendukung Keputusan

Tahap perancangan sistem pendukung keputusan penjurusan SMA menggunakan metode AHP terdiri dari hasil keputusan menggunakan AHP, metode yang digunakan dalam AHP dan user interface.

\section{Hasil Keputusan Menggunakan AHP}

Pada tampilan user interface sistem ini akan menampilkan hasil kriteria dari input yang telah dimasukkan oleh user, data yang diolah dan memperoleh hasil kriteria yang sesuai dengan siswa.

\section{IMPLEMENTASI}

\section{A. Prosedur Kegiatan AHP}

Pada dasarnya prosedur atau langkahlangkah dalam metode AHP meliputi : [7]

1. Mendefinisikan masalah dan menentukan solusi yang diinginkan, lalu menyusun hirarki dari permasalahan yang dihadapi.

2. Menentukan prioritas elemen.

3. Sintesis, yaitu pertimbangan-pertimbangan terhadap perbandingan berpasangan di-sintesis untuk memperoleh keseluruhan prioritas.

4. Mengukur Konsistensi, yaitu untuk mengetahui seberapa baik konsistensi yang ada karena kita tidak menginginkan keputusan berdasarkan pertimbangan dengan konsistensi yang rendah. Hal-hal yang dilakukan dalam langkah ini adalah :

1. Kalikan setiap nilai pada kolom pertama dengan prioritas relatif elemen pertama, dan seterusnya.

2. Jumlahkan setiap baris.

3. Hasil dari perjumlahan baris dibagi dengan elemen prioritas relatif yang bersangkutan.

4. Jumlah hasil bagi di atas dengan banyaknya elemen yang ada, hasilnya disebut $\lambda$ maks.

5. Hitung Consistency Index (CI) dengan rumus :

$$
\mathrm{CI}=(\lambda \text { maks }-\mathrm{n}) /(\mathrm{n}-1)
$$

Dimana $n=$ banyaknya elemen $/$ kriteria. 
6. Hitung Consistency Ratio (CR) dengan rumus :

Dimana

$$
\mathrm{CR}=\mathrm{CI} / \mathrm{IR}
$$

$\mathrm{CR}=$ Consistency Ratio

$\mathrm{CI}=$ Consistency Index

$\mathrm{IR}=$ Index Random Consistency

7. Memeriksa hirarki.

a. jika $\mathrm{CI}=0$ maka $\mathrm{A}$ konsisten

b. jika maka A cukup konsisten

c. jika maka A sangat tidak konsisten.

Tabel 4 adalah Daftar Indeks Random Konsistensi.

TABEL 4. DAFTAR INDEKS RANDOM KONSISTENSI

\begin{tabular}{|c|c|}
\hline Ukuran Matriks & Nilai IR \\
\hline 1,2 & 0.00 \\
\hline 3 & 0.58 \\
\hline 4 & 0.90 \\
\hline 5 & 1.12 \\
\hline 6 & 1.24 \\
\hline 7 & 1.32 \\
\hline 8 & 1.41 \\
\hline 9 & 1.45 \\
\hline 10 & 1.49 \\
\hline 11 & 1.51 \\
\hline 12 & 1.48 \\
\hline 13 & 1.56 \\
\hline 14 & 1.57 \\
\hline 15 & 1.59 \\
\hline
\end{tabular}

\section{B. Analisa Model AHP}

Dalam studi kasus ini mempunyai empat kriteria yang di antaranya dua kuantitatif dan dua kualitatif, serta tiga alternatif IPA, IPS, dan Bahasa.

Dalam AHP ada tiga tahap identifikasi :

1. Tentukan tujuan : Memilih jurusan SMA.

2. Tentukan kriteria : Nilai Akademik, nilai psikotest, minat, dan dari orang tua.

3. Tentukan Alternatif : IPA, IPS, dan Bahasa.

Gambar 3 adalah bentuk hirarki dari informasi yang diperoleh.

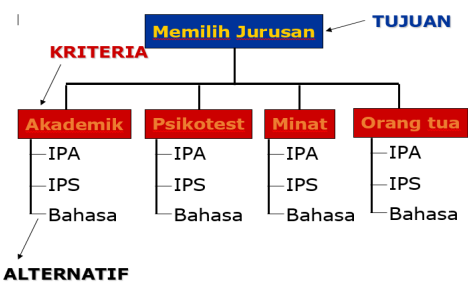

Gambar 3. Hierarki Informasi

1. Nilai Kuantitatif Kriteria

Dalam kasus ini ada 2 kriteria kuantitatif, yaitu nilai akademik dan nilai psikotest. Tabel 5 menggambarkan nilai-nilai tersebut.

TABEL 5. NILAI DARI KRITERIA KUANTITATIF

\begin{tabular}{|c|c|c|}
\hline \multirow{2}{*}{ Alternatif } & \multicolumn{2}{|c|}{ Kriteria } \\
\cline { 2 - 3 } & Akademik & Psikotes \\
\hline IPA & 75 & 90 \\
\hline IPS & 80 & 85 \\
\hline Bahasa & 70 & 80 \\
\hline
\end{tabular}

\section{Nilai Matriks Kriteria}

Tabel 5 adalah susunan kriteria-kriteria untuk pemilihan jurusan di SMA.

TABEL 5. SUSUNAN KRITERIA PEMILIHAN JURUSAN

\begin{tabular}{|c|c|c|c|c|}
\hline $\begin{array}{c}\text { Matriks } \\
\text { Kriteria }\end{array}$ & Akademik & Psikotest & Minat & $\begin{array}{c}\text { Orang } \\
\text { Tua }\end{array}$ \\
\hline Akademik & 1 & 3 & 3 & 5 \\
\hline Psikotest & $1 / 3$ & 1 & 1 & 3 \\
\hline Minat & $1 / 3$ & 1 & 1 & 3 \\
\hline Orang Tua & $1 / 5$ & $1 / 3$ & $1 / 3$ & 1 \\
\hline
\end{tabular}

3. Menghitung Rata-Rata / Bobot

Tabel 6 menunjukkan hasil rata-rata/bobot dari setiap kriteria.

TABEL 6. HASIL RATA-RATA SETIAP KRITERIA

\begin{tabular}{|c|c|c|c|c|}
\hline \multicolumn{3}{|c|}{ Rata-rata dari setiap Kriteria } & Rata-Rata \\
\cline { 4 - 5 } & Kriteria \\
\hline 0.5357 & 0.5625 & 0.5625 & 0.4167 & 0.5193 \\
\hline 0.1786 & 0.1875 & 0.1875 & 0.2500 & 0.2009 \\
\hline 0.1786 & 0.1875 & 0.1875 & 0.2500 & 0.2009 \\
\hline 0.1071 & 0.0625 & 0.0625 & 0.0833 & 0.0789 \\
\hline
\end{tabular}




\section{Menghitung Hasil Matriks}

Menghitung hasil matriks dari matrik yang ada di nomer 2. Caranya dengan perkalian matriks dan rata-rata kriteria. Dengan hasil seperti matriks berikut:

$\left(\begin{array}{cccc}1 & 3 & 3 & 5 \\ 1 / 3 & 1 & 1 & 3 \\ 1 / 3 & 1 & 1 & 3 \\ 1 / 5 & 1 / 3 & 1 / 3 & 1\end{array}\right)\left(\begin{array}{l}0.5193 \\ 0.2009 \\ 0.2009 \\ 0.0789\end{array}\right)=\left(\begin{array}{l}2.1190 \\ 0.8115 \\ 0.8115 \\ 0.3167\end{array}\right)$

5. Memeriksa Konsistensi

Uji konsistensi: Misalkan A adalah matriks perbandingan berpasangan, dan $\mathrm{w}$ adalah vektor bobot, maka konsistensi dari vektor bobot $\mathrm{w}$ dapat diuji sebagai berikut:

1. Hitung $\mathrm{T}$

$\mathrm{T}=$ Hasil Matriks / Rata-rata Kriteria

$$
\left(\begin{array}{l}
2.1190 \\
0.8115 \\
0.8115 \\
0.3167
\end{array}\right) \div\left(\begin{array}{l}
0.5193 \\
0.2009 \\
0.2009 \\
0.0789
\end{array}\right)=\left(\begin{array}{l}
4.0802 \\
4.0395 \\
4.0395 \\
4.0151
\end{array}\right)
$$

2. Hitung $\lambda$ maks

$$
\lambda=\frac{1}{n} \sum_{i=1}^{n}\left(\frac{\text { elemen } \mathrm{ke}-\mathrm{i} \text { pada }(\mathrm{A})\left(\mathrm{w}^{\mathrm{T}}\right)}{\text { elemen } \mathrm{ke}-\mathrm{i} \text { pada } \mathrm{w}^{\mathrm{T}}}\right)
$$

Untuk $\mathrm{n}=4$

$\lambda=4.0436$

3. Hitung Index

$$
\begin{array}{r}
C I=\frac{\lambda-n}{n-1} \\
C I=\frac{4.0436-4}{4-1} \\
C I=0.0145
\end{array}
$$

4. Rasio Konsistensi

Rumus

$$
C R=\frac{C I}{R I}
$$

Untuk n $=4, \mathrm{RI}=0.90$, maka :

$$
\begin{aligned}
& C R=\frac{0.0145}{0.90} \\
& C R=0.0161
\end{aligned}
$$

Karena CR $<0.100$ berarti preferensi responden adalah konsisten.

\section{Menentukan Nilai Bobot (w)}

Untuk menghitung bobot pada kriteria dilakukan perbandingan kriteria-kriteria yang ada, tetapi untuk kriteria kuantitatif menggunakan rumus maks atau min (tergantung kriterianya).

1. Kriteria Kuantitatif

$$
\begin{aligned}
& M A X=\frac{\text { NilaiKriteria }}{\text { MaxdariNilaiKriteria }} \\
& w=\frac{\text { HasildariNilaiKriteria }}{\sum \text { HasildariNilaiKriteria }}
\end{aligned}
$$

a. Nilai Akademik

Hasil dari perhitungan kriteria akademik ditunjukkan pada Tabel 7 .

\section{TABEL 7. HASIL HITUNG TIAP KRITERIA}

\begin{tabular}{|c|c|c|}
\hline \multirow{2}{*}{} & \multicolumn{2}{|c|}{ Akademik (MAX) } \\
\cline { 2 - 3 } & 80 & $\mathrm{w}$ \\
\hline IPA & 0.94 & 0.3333 \\
\hline IPS & 1.00 & 0.3556 \\
\hline Bahasa & 0.88 & 0.3111 \\
\hline Jumlah $=$ & 2.81 & \multicolumn{2}{|l}{} \\
\hline
\end{tabular}

b. Nilai Psikotes

Hasil dari perhitungan kriteria psikotes ditunjukkan pada Tabel 8.

TABEL 8. HASIL HITUNG KRITERIA PSIKOTES

\begin{tabular}{|c|c|c|}
\hline \multirow{2}{*}{} & \multicolumn{2}{|c|}{ Psikotes (MAX) } \\
\cline { 2 - 3 } & 90 & $\mathrm{w}$ \\
\hline IPA & 1.00 & 0.3529 \\
\hline IPS & 0.94 & 0.3333 \\
\hline Bahasa & 0.89 & 0.3137 \\
\hline Jumlah $=$ & 2.83 & \multicolumn{2}{|l}{} \\
\hline
\end{tabular}

Keterangan : 80 adalah nilai maximum dari nilai kriteria akademik dan 90 adalah nilai maximum dari nilai kriteria psikotes.

\section{Kriteria Kualitatif}

Cara untuk mencari bobot dari kriteria kualitatif ada langkahnya, yaitu :

1. Lakukan perbandingan matriks antara alternatif yang sudah ditentukan.

2. Cari rata-rata matriks tersebut, dan 
3. Rata-rata tersebut lah yang menjadi nilainilai bobot pada kriteria kualitatif

a. Matriks Orang Tua

\begin{tabular}{cccc}
\multicolumn{4}{c}{ Bahasa $(1)<$ IPS $(3)<$ IPA (5) } \\
$\begin{array}{c}\text { Matriks } \\
\text { Ortu }\end{array}$ & Bahasa & IPS & IPA \\
Bahasa & 1 & $1 / 3$ & $1 / 5$ \\
IPS & 3 & 1 & 3 \\
IPA & 5 & $1 / 3$ & 1
\end{tabular}

$\begin{array}{lccc}0.1111 & 0.20 & 0.0476 & \begin{array}{c}\text { Rata-Rata } \\ (\text { Bobot/w) }\end{array} \\ & 0.1196 \\ 0.3333 & \begin{array}{c}0.60 \\ 00\end{array} & 0.7143 & 0.5492 \\ 0.5556 & \begin{array}{c}0.20 \\ 00\end{array} & 0.2381 & 0.3312\end{array}$

b. Matrik Minat

IPA (1) < Bahasa (3) $<$ IPS (5)

\begin{tabular}{|c|c|c|c|}
\hline $\begin{array}{c}\text { Matriks } \\
\text { Minat }\end{array}$ & IPA & Bahasa & IPS \\
\hline IPA & 1 & $1 / 3$ & $1 / 5$ \\
\hline Bahasa & 3 & 1 & 3 \\
\hline IPS & 5 & $1 / 3$ & 1 \\
\hline
\end{tabular}

\begin{tabular}{|c|c|c|c|}
\cline { 3 - 4 } \multicolumn{2}{c|}{} & $\begin{array}{c}\text { Rata-Rata } \\
(\text { Bobot/w) }\end{array}$ \\
\hline $\begin{array}{c}0.11 \\
11\end{array}$ & 0.2000 & $\begin{array}{c}0.04 \\
76\end{array}$ & 0.1196 \\
\hline $\begin{array}{c}0.33 \\
33\end{array}$ & 0.6000 & $\begin{array}{c}0.71 \\
43\end{array}$ & 0.5492 \\
\hline $\begin{array}{c}0.55 \\
56\end{array}$ & 0.2000 & $\begin{array}{c}0.23 \\
81\end{array}$ & 0.3312 \\
\hline
\end{tabular}

\section{Hasil Akhir Perhitungan}

Setelah semua bobot dari kriteria sudah dicari, selanjutnya mencari hasil akhir matriks. Tabel 9 adalah penggabungan nilai-nilai bobot dari kriteria.
TABEL 9. NILAI GABUNGAN BOBOT KRITERIA

\begin{tabular}{|c|c|c|c|}
\hline Akademik & Psikotest & Orang Tua & Minat \\
\hline 0.3333 & 0.3529 & 0.3312 & 0.1196 \\
\hline 0.3556 & 0.3333 & 0.5492 & 0.3312 \\
\hline 0.3111 & 0.3137 & 0.1196 & 0.5492 \\
\hline
\end{tabular}

Dan di bawah ini adalah hasil matriks dari nilai bobot yang dihitung dengan perkalian matriks tersebut :

$$
\left(\begin{array}{llll}
0.3333 & 0.3529 & 0.3312 & 0.1196 \\
0.3556 & 0.3333 & 0.5492 & 0.3312 \\
0.3111 & 0.3137 & 0.1196 & 0.5492
\end{array}\right)\left(\begin{array}{l}
0.5193 \\
0.2009 \\
0.2009 \\
0.0789
\end{array}\right)=\left(\begin{array}{l}
0.3200 \\
0.3881 \\
0.2919
\end{array}\right)
$$

Dengan hasil akhir di atas, nilai untuk IPA = 0.3200 , IPS $=0.3881$, dan Bahasa $=0.2919$. Jadi dapat disimpulkan alternatif yang dipakai atau jurusan yang menjadi keputusan metode ini adalah jurusan IPS.

\section{KESIMPULAN}

Model AHP dapat digunakan untuk membantu mendapatkan alternatif penjurusan pada pada tingkat SMA dengan menggunakan pertimbangan kriteria dan alternatif jurusan lain sesuai dengan hasil dari peminatan, nilai akademik dan hasil psikotes.

\section{REFERENCES}

[1] Turban, Efraim \& Aronson, Jay E. 2001. Decision Support Systems and Intelligent Systems. 6th edition. Prentice Hall: Upper Saddle River, NJ.

[2] Sparague, R. H. and Watson H. J. 1993. Decision Support Systems: Putting Theory Into Practice. Englewood Clifts, N. J., Prentice Hall.

[3] Jogiyanto, H.M. 2010. Analisis dan Desain Sistem Informasi Edisi IV. Yogyakarta: Andi.

[4] Yusuf. Masagus M, 2017. Rancang Bangun Sistem Pendukung Keputusan Penjurusan Siswa Sma/Ma Menggunakan Metode Analytical Hierarchy Process (Studi Kasus: Man Bontang), Jurnal Sains Terapan Teknologi Informasi.

[5] Nurdiyanto, Heri \& Minarto, Sulung Yoga. 2016. Sistem Pendukung Keputusan Pemberian Kredit pada Koperasi Serba Usaha Berkah Tiram Jaya Menggunakan Metode Analytic Hierarchy Process (AHP). Seminar Nasional Universitas PGRI Yogyakarta Volume 1.

[6] Kusumo, Idam W. 2011. Pengembangan Aplikasi Sistem Pendukung Keputusan dalam Pemilihan Fakultas Perguruan Tinggi Berbasis Web Mobile. Skripsi. UIN Syarif Hidayatullah Jakarta.

[7] Wirastama, Nufus. 2013. Sistem Pendukung Keputusan Pemilihan Program Studi pada Perguruan Tinggi Melalui Jalur SNMPTN pada SMAN 16 Semarang. Skripsi. Universitas Dian Nuswantoro. 